\title{
LEARNING ISLAM FROM THE PERFORMANCE OF WAYANG KULIT (SHADOW PUPPETS)
}

\author{
Ferdi Arifin \\ IAIN Surakarta \\ Jl. Pandawa, Pucangan, Kartasura, Sukoharjo, Jawa Tengah \\ Email: ferdi.arifin@iain-surakarta.ac.id
}

\begin{abstract}
Abstrack. Shadow puppet is the oldest heritage culture in Indonesia. There are many local wisdom values embedded in shadow puppet, so it can be a reason of the existence of shadow puppet throughout the ages. One of facts shows us that shadow puppet is well-knows as the greatest heritage for a history of spreading Islam used to a shadow puppet media by Sunan Kalijaga. This research employs qualitative method which direct observes this performing arts to find facts that shows shadow puppet is being regarded as dawa media. In fact, shadow puppet has essential role for spreading Islam in Indonesia because it has a linier values with Islam itself. The result explains us that language facts derives from wejangan form in shadow puppet representing Islamic values. Therefore, shadow puppet can be a Islamic learning media for all people.
\end{abstract}

Abstrak. Wayang kulit merupakan seni pertunjukkan paling kuno di Indonesia. Banyaknya nilai-nilai luhur yang melekat dengan wayang kulit menjadikannya mampu bertahan mengikuti zaman. Salah satu fakta wayang kulit sebagai hasil budaya yang luar biasa adalah sejarah penyebaran Islam menggunakan wayang kulit yang dilakukan oleh Sunan Kalijaga. Penelitian ini menggunakan metode kualitatif dengan observasi seni pertunjukkan wayang untuk menemukan fakta bahwa wayang kulit menjadi sarana yang bagus untuk media dakwah. Bagaimanakah peran wayang kulit dalam mempertahankan nilainilai budaya yang selaras dengan unsur-unsur keislaman. Hasil penelitian ini menunjukkan bahwa fakta bahasa yang muncul dari bentuk-bentuk wejangan dalam cerita wayang selarah dengan ajaran-ajaran Islam. Selain itu, lakon yang dimainkan dalam wayang juga mencerminkan nilai-nilai Islam. Dengan 
Vol. 14, No. 1 Juni 2017: 99-115

demikian, wayang kulit bisa menjadi sarana pembelajaran Islam yang baik untuk anak-anak maupun dewasa.

Keywords: Media of Islamic Learning, wayang kulit (shadow puppet)

DOI: http://dx.doi.org/10.24239/jsi.v14i1.457.99-115

\section{Introduction}

In the era of globalization, wayang kulit or shadow puppets is one of the oldest cultural heritages that still exist until today. The existence of wayang kulit itself cannot be separated from the role of people who made an effort to preserve it in various ways, either in entertainment or cultural events, such as merti desa. In its history, wayang kulit is an artifact of the community in the past in performing rituals of worshipping the spirits. Wayang takes an important role in the process of ritual ceremony in the form of stage show with hymn chanting directed to the ancestral spirits. It was believed as a form of asking for help to the ancestral spirits in helping them in running social life. ${ }^{1}$

However, the development of wayang nowadays is much more different from that of ancient wayang. Since wayang kulit is used as a medium of propagation by Sunan Kalijaga, it has many roles. In addition to a means of propagation, wayang can also take entertaining and educational role. Furthermore, there are still some people who use wayang as ritual media. Change of roles like this cannot be separated from the development of the era followed by the development of wayang, as the impact of the people who have started to leave a belief in animism and dynamism. ${ }^{2}$

The impact of changes caused by the success of Sunan Kalijaga in spreading Islam through wayang kulit has an impact on the popularity of wayang kulit as a medium of $d a^{\prime} w a h$ as well

\footnotetext{
${ }^{1}$ S. Mulyono, Wayang: Asal Usul, Filsafat, Dan Masa Depannya (Jakarta: PT. Gunung Agung, 1987). 45-50

${ }^{2}$ F. Arifin, “Ajaran Moral Resi Bisma Dalam Pewayangan," Jantra: Jurnal Sejarah dan Budaya 9, no. 2 (2014): 97-106. 97
} 
as entertainment for the community. There are several examples of the play perfomed in such a way to learn Islam, such as the stories of Dewa Ruci, Kalimasada Kajarwa, Kumbayana Ngejawa, Jaladara Rabi, Petruk Dadi Ratu, and so on. Some of the stories are very synonymous with Islamic values, but packaged in Javanese culture which is still thick with animism and dynamism.

Wayang is seen as a neat cultural heritage packed as a medium of learning. This is because show of wayang kulit has uniqueness and sophistication in its performances because it combines a variety of art, such as dramatic art when narrating the story, singing art in each song, and fine art in the process of character formation, etc. ${ }^{3}$ The number of uniqueness possessed by art of wayang makes it popular and effective to be a media of propagating Islam by Sunan Kalijaga. In fact, wayang kulit is also a means for character education. ${ }^{4}$ Therefore, it is not surprising that Sunan Kalijaga succeed in disseminating Islamic values because the messages conveyed in wayang kulit are basically in line with Islamic values.

This research will analyse the role of wayang kulit as media of Islamic learning. This is because there are so many attempts to misunderstand the notion that wayang kulit is not as an Islamic culture. Although it cannot be denied that the true wayang as a heritage of animism and dynamism in the archipelago at that time, but it cannot be also denied that Sunan Kalijaga successfully acculturated the heritage of wayang kulit as a medium of Islamic learning is quite effectively accepted and disseminated to various parts of the region. In fact, the model performed by Sunan Kalijaga was repeatedly reproduced by some current dalangs as an attempt to convey the message of Islamic beauty and Islamic values. 1999). 21

${ }^{3}$ B. Hasrinuksmo, Ensiklopedi Wayang Indonesia (Jakarta: Sena Wangi,

${ }^{4}$ F. Arifin, "Wayang Kulit Sebagai Media Pendidikan Budi Pekerti," Jantra: Jurnal Sejarah Dan Budaya 8, no. 1 (2013): 75-82. 78 


\section{Method}

To see how the role of wayang kulit as a means of Islamic education, this research uses a qualitative research as a model which is deeply rooted in the study of the humanities and other sciences. ${ }^{5}$ This is because the qualitative research model is able to see very complex situations in social phenomena. ${ }^{6}$. The qualitative research model is also the most mature methodology so far and often used by social researchers. ${ }^{7}$

With this qualitative method, I will do direct observation of wayang kulit show that correlates with the media of Islamic education. This observation involves watching wayang kulit show directly and uploaded video in YouTube. This make me easy to see closely at any cultural patterns of wayang kulit. This research model such as self-involvement into direct situations in society can lead to an in-depth description of the patterns. ${ }^{8}$

Collecting data directly and involving two-way communication between the researcher and the object of research will provide a more fair picture in this study. Aspect of language will also be highlighted to see how a language used in wayang kulit reflects people's mindset in it. In addition, the depiction of wayang kulit story and play is also symbols created by culture through a long process of agreement.

${ }^{5}$ B. Kaplan et al., "E. Learning and Teaching Qualitative Research: A View from Reference Disciplines of History and Anthropology," in Organizational and Social Perspectives on IT, 2000, 511, http://is.lse.ac.uk/Support/ifip_wg82/ Aalborg/kaplan.pdf .

${ }^{6}$ J. Atkins, S.Volmink et al., "Conducting a Meta-Ethnography of Qualitative Literature: Lessons Learnt," BMC Medical Research Methodology 8, no. 21 (2008), doi:https://doi.org/10.1186/1471-2288-8-21.; C. Shelton and A. Smith, "On the Qualities of Qualitative Research, Qualités de La Recherche Qualitative," Canadian Journal of Anesthesia/Journal Canadien D'anesthésie 62, no. 1 (2015), doi:https://doi.org/10.1007/s12630-014-0253-3.

${ }^{7} \mathrm{~J}$. Liebenau and A. Lee, "Information System and Qualitative Research," The Lancet 348, no. 9020 (1996): 127-28, doi:https://doi.org /10.1016/S01406736(05)64639-9.

${ }^{8}$ C. Geertz, Tafsir Kebudayaan (Yogyakarta: Penerbit Kanisius, 1992). 12 
Thus, the results of the research will provide an overview of the potential of art of wayang kulit in Islamic education in this multicultural society. Therefore, this part of the study will present how the pattern of language that emerges in wayang kulit correlates with Islamic education, and depiction of the play of wayang kulit is a part of symbol agreement to reflect the entire human being.

\section{Islamic Values through the Use of Wayang Kulit Language in the perspective of Cognitive Linguistics}

So far, most societies regard language as a tool for communicating between people. However, the role of language in fact is more than just a means of communication. For Ferdinand de Saussure's followers, language is regarded as a convention of structured and meaningful sound symbols that refer to a particular object. ${ }^{9}$ However, in the perspective of cognitive linguistics, language is not merely a symbolic convention that refers to a particular object but as a result of human thought. For followers of cognitive linguistics school, language not only reflects the world directly, but as a conceptualization of the mind in interpreting the world..$^{10}$

This cognitive linguistic model is influenced by the view of the relativist Wilhem von Humboldt who sees the structure of language as a reflection of the world and correlates with the human mind, way of life, and the influencing culture. ${ }^{11}$ This was then followed by an anthropologist Franz Boaz and later developed by Edward Sapir and Benjamin Lee Whorf who sparked Sapir-Whorf Hypothesis. Hypothesis which is then developed is the fact that language that emerged from a society contains

${ }^{9}$ Saussure, Course in General Linguistics, ed. C. Bally and A. Sechehaye (New York: McGraw-Hill Book Company, n.d.). 65-70

${ }^{10}$ Wierzbicka, Semantics, Cognition, and Culture (London: Oxford University Press, 1992). 7.

${ }^{11}$ Trask, Key Concept in Language and Linguistic (New York: Routledge, 1999). 112 
essential essence in a cultural expression; that is, there is a correlation between the structure of the universe and language structure. $^{12}$

The use of language in this wayang kulit reflects man's mindset of the universe. The language of wayang is so far the most original language because it is not easily influenced by foreign language interference. This is because the language in wayang is considered as a fixed language so that it continues to be maintained from time to time. In other words, this research will reveal the facts of language in wayang that reflect a message of Islamic education to the public.

SENGKUNI: manawi Janaka menika tumandang ngupaya wahyu, Kurawa mboten badhé ngukup menapa-menapa. (if Janaka start looking for revelation, surely Kurawa will not get anything)

DURNA: 'Ko 'sik 'Dhi Cuni, aja cilik ati. Wong kuwi kudu sing nrima. Narima iku tumanggaping ati ingkang jembar. (wait my sister, Cuni. Do not be discouraged. The man should be submissive. Resignation used wide heart)

As a teacher, Durna advised Sengkuni who is a royal officer by using the phrase aja cilik ati "do not be discouraged" and wong kuwi kudu sing nrima "that person must be resigned". The context is taken from the story of Makutharama played by a puppeteer Ki Purbo Asmoro.

Although the public knows that Durna and Sengkuni are antagonistic figures, but in puppetry, they basically never justify that a person is good or bad, but invites the puppet lovers to see a situation from another perspective. In that case, Durna gives advise to Sengkuni not to despair and become a surrender to God. Islam always teaches its people not to be easily despaired and submissive to God through the Quran and Hadith.

${ }^{12}$ A. Duranti, Linguistic Anthropology (New York: Cambridge University Press, 1997). 56-58 


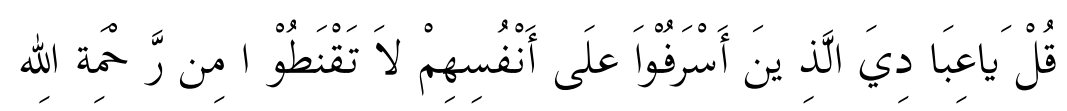

Say, "O My servants who have transgressed against themselves [by sinning], do not despair of the mercy of Allah . Indeed, Allah forgives all sins. Indeed, it is $\mathrm{He}$ who is the Forgiving, the Merciful." ( Q.S. al-Zumar [39]: 53).

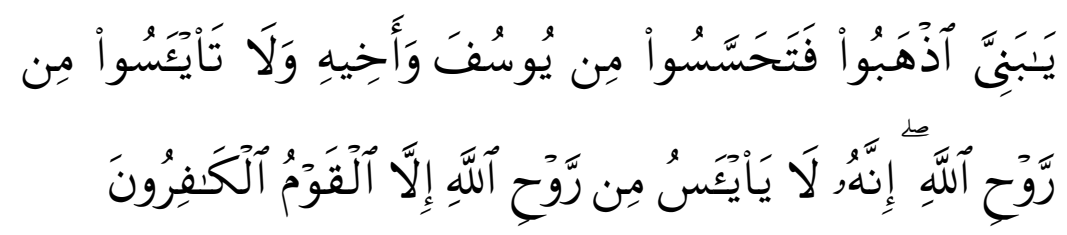

O my sons, go and find out about Joseph and his brother and despair not of relief from Allah. Indeed, no one despairs of relief from Allah except the disbelieving people." (Q.S. Yusuf [12]: 87)

These Quranic verses urge Muslims to continue to fight and not despair because Allah always gives a beautiful end according to the condition of his servant. The Quran teaches people not to despair of God's mercy because despair is the act of unbelievers (kāfir).

These two verses are in line with Durna's advise to Sengkuni who despaired of God's mercy because she considered God's mercy applies only to certain people, described as a figure of Arjuna. Although Durna not explicitly explained the elements of Islam, but it is in line with the call of Allah in the holy Quran:

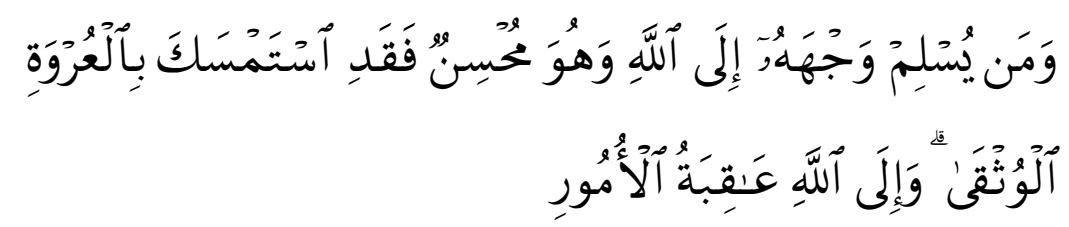

And whoever submits his face to Allah while he is a doer of good - then he has grasped the most trustworthy handhold. And to Allah will be the outcome of [all] matters (Q.S. Luqman [31]: 22). 
The concept of submission is also explained in the sura of Luqman verse 22 which explains that surrendering to God is a virtue. It was revealed by Durna to Sengkuni who seemed not accept the circumstances.

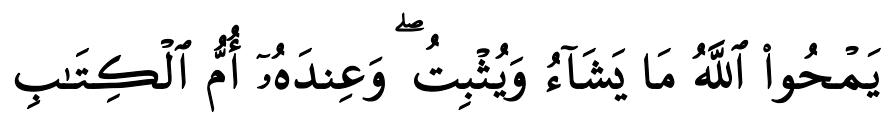

Allah eliminates what He wills or confirms, and with Him is the Mother of the Book. (Q.S. al-Ra'd [13]: 39)

Being resigned (tawakkul) has also been explained in the Quran, al-Ra'd verse 39. This is because everything that happened is destined by Allah so that man should surrender to Him. All things happening in this world have been written in the ummul kitab. Therefore, Durna's message to Sengkuni to surrender because all the provisions that exist in this world have been determined.

The language that appeared in the conversation between Durna and Sengkuni is the result of human thinking that correlates with the world. In other words, the message Durna to Sengkuni not necessarily interpreted literally, but also symbolically; that is a message to humans not to give up easily and be resigned. The selection of the phrase is because a lot of people easily give up because they feel inferior to others, and also many people impose their will and expect so high. And in turn it leads to disappointment because desire and expectation are not in accordance with reality.

In addition to the conversation between Durna and Sengkuni, the example that describes wayang language as a medium of Islamic education is Wibisana's speech to the Pandavas. Here is a fragment of a Wibisana conversation.

WIBISANA: Ya iya 'nggèr. Lakuning urip iku, Sepisan: beciking kelakuwan saranané kudu hanggulang welas asih, nancepaké rasa 'sih tresna. Kang kapindhoné: akèhing kepinteran, saranané kudu nlatèni pasinaon sarta ora isin tetakon. Kateluné: pakolèhing kagunan, saranané kudu tetulung marang liyan. Banjur ingkang angka catur: sugih, 
saranané kudu anggedhèkaké panggaotan kanthi gemi, surti, nastiti, ngati-ati sarta tumungkul pamikiré. Kaping lima: ngudi singgih, saranané kudu manggung angudi kawruh pangrèh praja, sarta nuntuni tata tentrem, tata patrapé wong omah-omah tentrem jenjeming ati. Angka nenem: buntasing sesurupan, saranané kudu gegosokan panemu, sarta anggilut marang surasaning basa. Ingkang wekasan: landheping panggrahita, saranané kudu ngulataké cipta sasmita, yaiku mawas rasaning patrap lan pangucap apadéné kedhèp sasmita sarta ulat liring nganti bisa hanampani rasaning liyan ingkang ora kawedhar, utawa, nampakaké rasané dhéwé marang wong liya. Iku kulup, sapta ingkang wus ingsun paringaké marang jenengpara kaki, kena kinarya gegaran.

In this example, Wibisana is giving advise to the Pandavas to live a good life. From this Wibisana's message, there are seven ways to live a good life: beciking kelakuan, akehinng kepinteran, pakolehing kagunan, sugih, ngudi singgih, buntasing sesurupan, and landheping panggahita. Being good, smart, useful, rich, respectable, polite, and insightful are the forms of positive action taught in Islam.

There are a lot of Quranic verses and the Hadith of the Prophet that confirm Wibisana's advise.

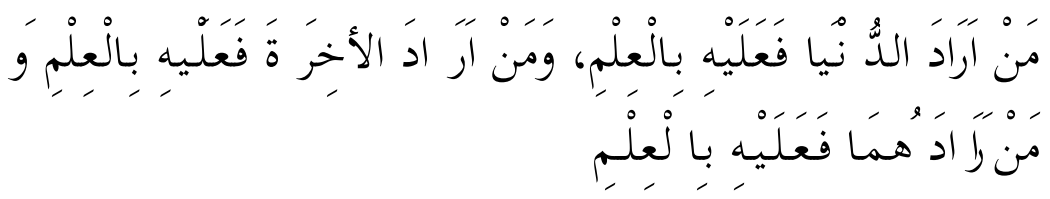

"Whoever wants the world, he must have knowledge. And whoever wants happiness in the Hereafter, he must have knowledge. And whoever wants both, he must also have knowledge of both." (Within the boundaries blessed by Allah) (Al-Bukhari and Muslim).

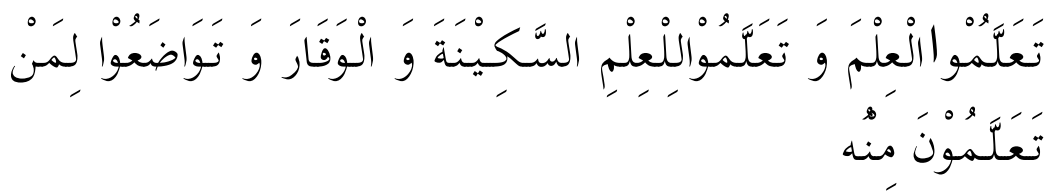

"Seek knowledge and science, and learn peace and honor for this science. And be humble to the one who teaches you (Muslim)."

Both hadith clarified Wibisana's advise that in living a life, knowledge and insight are needed to achieve the good in the 
world and the hereafter. The first hadith from Bukhari and Muslim explains to us that to be happy in this world and the hereafter, to seek knowledge is obligatory. This is because Islam commands his people to study and seek knowledge in order to obtain happiness in this world and the hereafter.

Education itself is an attempt to think critically in the face of a problem. In other words, education is a form of consciousness that can help one interpret the problem through analysis from different views and perspectives. ${ }^{13}$. In Wibisana's words, the advises which were given used languages that reflect community's thought by using words and phrases that refer to the messages of learning science and life. This is in harmony with the teachings of Islam that require humans to seek knowledge to obtain the happiness in this world and the hereafter as well as tranquility and self-respect.

Wibisana's advise is not separated from the culture of the community that own wayang kulit. Moreover, if it is viewed from cognitive linguistic that language is a reflection of the humans' mind and their cultural concepts. Therefore, the discourse raised by the play of Wibisana is a message for society that is transformed through community's culture in oder to be more easily understood. In other words, the language described above is an attempt to educate people through the performance of the art of wayang kulit. Therefore, it is not surprising if Sunan Kalijaga used wayang kulit as a medium of Islamic propagation at that time due to myriad of Islamic values reflected in the art of wayang kulit.

\section{Story of Wayang Kulit as A Symbol of Islamic Community Model}

In recent years, Islam has experienced a crisis of confidence from the world. This is because a lot of crimes, such as murder,

\footnotetext{
${ }^{13}$ Paulo Freire, Education For Critical Consciousness (London: Continuum, 2005). 3-20.
} 
terrorism, violence, etc., use Islamic symbols. Islamic symbols such as caps, turbans, dresses, and all-white clothes are often used by people in their activity. As a result, society's perspective on Islam is bad because the image of Islam was tarnished from the clothing used by the perpetrators.

In addition, the actions that echo the name of God arise to perform actions that do not actually reflect islamic teachings. Moreover, in Indonesia today there are many mass organizations that intend to establish the Islamic State under one great leadership, and descredit Pancasila values and Bhineka Tunggal Ika. It can be argued that the acts which descredit the basis of the State have been regarded as acts of treason. Worse yet, the actions actually create divisions within Islam itself.

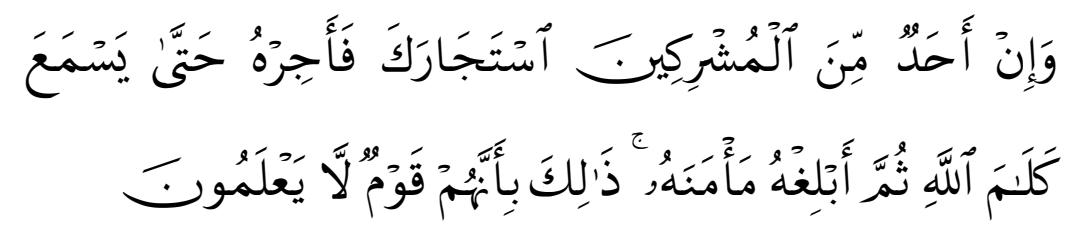

And if any one of the polytheists seeks your protection, then grant him protection so that he may hear the words of Allah. Then deliver him to his place of safety. That is because they are a people who do not know (Q.S. At-Taubah [9]: 6).

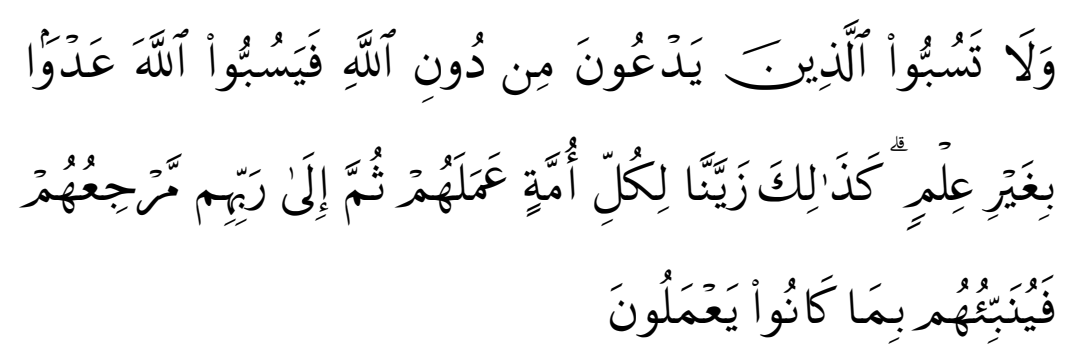

And do not insult those they invoke other than Allah, lest they insult Allah in enmity without knowledge. Thus We have made pleasing to every community their deeds. Then to their Lord is their return, and He will inform them about what they used to do (QS. An'am: 108). 


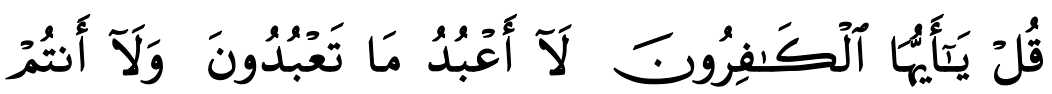

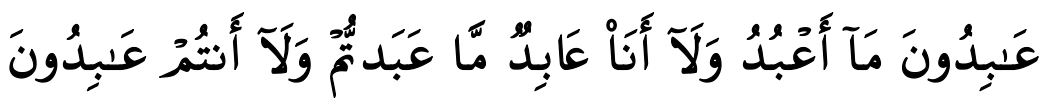

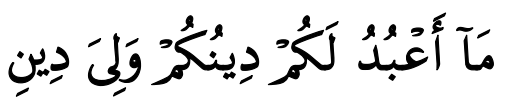

(1) Say, "O disbelievers, (2) I do not worship what you worship. (3) Nor are you worshippers of what I worship; (4) Nor will I be a worshipper of what you worshi (5) Nor will you be worshippers of what I worship (6) For you is your religion, and for me is my religion.

In such surah as al-Taubah (6), Al-An'am (108), and AlKafiruun (1-6), it is indicated that Islam loves peace in all things, including in addressing other religions. It is shown clearly that those verses call Muslims to protect one another and not to criticize each other for religious differences. It is reinforced by AlKafiruun (1-6) that every religion has its own affairs and Muslims are forbidden to impose their will to others in terms of religious convictions.

It can be concluded that Islam is actually a religion of peace. Therefore, it is surprising if there are terrorists who claim doing crimes in the name of Islam because Islam itself is actually religion of peace. In other words, those who profess Islam must be tolerant and promote nationalism through their diversity.

In wayang play, tolerance, nationalism, and respecting human's dignity are strongly emphasized in all its characters. A Kumbokarna, the sister of Ravana, is a true nationalist figure for defending her country despite her intersection with her own brother. Kumbokarno is depicted as a giant who likes to eat and sleep, not obeying his brother's orders that violate the nature of life. However, Kumbokarno remains a figure who stands at the forefront against Rama and Lesmana who want to destroy Alengka because the mission of Rama, Lesmana, and Hanoman to take back Dewi Sinta. 
Rahwana's behaviour who abducted Sinta made two great kingdoms, Ayodya and Alengka, strife and resulted in a great war. However, Rama and his troops, who are described as protagonists, arrived to take his wife by destroying Alengka and Ravana. This made Kumbokarno as a true nationalist not to tolerate it. He did not care who is right and wrong, regarding the fight between Rama and Ravana. What is in Kumbokarno's mind is only to defend the State. Whoever destroys the State of Alengka, means he is his enemy, although Rama and his troops are imaged as protagonists. Still, destroying Alengka is just as hostile to Kumbokarno.

Basically, nationalism is a transformation of the attitude adopted by a person in politicizing his own ethnicity to create a clear identity of a territory. ${ }^{14}$ It also forms the identity of a nation..$^{15}$ Kumbokarno is one of the examples of the play in the puppet who maintains the values and identity of the nation. In other words, regardless of the person, if he disturbs the values and the identity of his people, it means that he is his enemy.

What Kumbokarno did can be regarded as a nationalist behavior because of the symbols that arise from the characters and behaviors are clearly shown. Such symbol system appears due to the presence of markers and signs. ${ }^{16}$ Although Kumbokarno is described as a giant who likes to eat and sleep, but when there are people who harass his country, he wakes up and fights against those who disrupt the stability of the State.

\footnotetext{
${ }^{14} \mathrm{~S}$. Joireman, Nationalism and Political Identity (New York: Continuum, 2003), doi:https://doi.org/10.1057/ palgrave.cpt.9300195.

${ }^{15}$ M. Root, B., \& Albrecht, "Influences of Nationalisms on Citizenship Education: Revealing a 'dark Side' in Lebanon,” Nations and Nationalism, 2017.

${ }^{16}$ Trask, Key Concept in Language and Linguistic. 201
} 


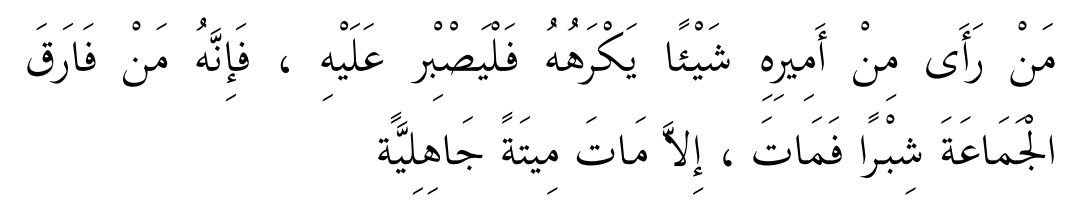

"Whoever disapproves of something done by his ruler then he should be patient, for whoever disobeys the ruler even a little (little = a span) will die as those who died in the Pre-lslamic Period of Ignorance. (i.e. as rebellious Sinners) (Bukhari)."

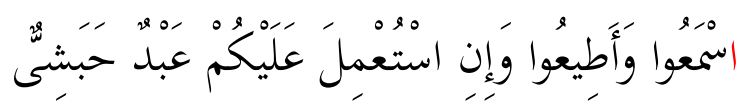

"Listen and obey your leaders, even if he is a Habsy slave (HR. Bukhari)."

The hadith narrated by Bukhari emphasizes that man should have the soul of nationalism. It is also explained that someone who behaves and acts against the government can be regarded as a crime. In this case, Kumbokarno actually gives a nationalist picture who protects his people from outside interference.

It is necessary to understand today that separatist movements against the State raise the issue of unilateral independence. This case often makes people feel terrorized, so that the movement they perceived as a movement for jihad actually turned into a terror movement. Terror is acts of repression that has a great impact to society and the State (Cooney \& Bigman, 2015: 25-46). In fact, terror movements always oust others for the benefit of their own group.

The real case that emerged among the people of Indonesia is that wayang kulit is not part of Islam. This statement is the most obvious form of propagation from the repressive movement to an existing thing.

In a pragmatic study, the phrase expressed has a meaning bound to another meaning; that is, it has explicit and implied 
meaning. ${ }^{17}$ When understood in explicit meanings, the picture shows that wayang kulit is not the culture and teachings of Islam Meanwhile, the implicit meaning includes a prohibition to watch wayang kulit. Although the fact of history explains that wayang kulit is not Islamic culture, but it becomes a powerful educational media used by Sunan Kalijaga in Islamic propagation. On the other hand, wayang kulit mostly teaches people to live like what is taught by Islam, such as story of Kumbokarno and other advises in wayang kulit.

\section{Conclusion}

Wayang kulit is the heritage of the oldest Nusantara culture that still exists to this day. The rapid development of the era may have eliminated many local cultures, but the fact that this development has not undermined the existence of wayang kulit at all. In fact, wayang kulit still can be enjoyed today by people anywhere and anytime.

The success of wayang kulit to survive in the midst of modern times shows that the values contained in wayang are abundant. Sunan Kalijaga who understands wayang kulit carefully can recognize that this culture is so extraordinary that it is used as media to spread the religion of Islam. Currently, many narrators or dalang also use this for media of Islamic propagation, such as Ki Enthus who always takes time to deliver the Quranic verses and the hadith of the prophet.

The language used in giving advises also contains Islamic values, so it is very easy to convey Islamic education through this performance. In addition, story in the performance of wayang which used the setting of the Hindu-Buddhist kingdom was actually attached to the teachings of Islam

Religious learning through the media of arts will be more easily accepted by various circles of society rather than direct

\footnotetext{
${ }^{17}$ Yule, Pragmatics (Oxford: Oxford University Press, 1996). 3-4
} 
learning. This is because music, literature, and painting collaborate to create beauty in giving good message and impression. Therefore, the existence of wayang kulit can be used as a good Islamic learning media as well as an effort to preserve cultural heritage.

\section{Bibliography}

Arifin, F. “Ajaran Moral Resi Bisma Dalam Pewayangan.” Jantra: Jurnal Sejarah Dan Budaya 9, no. 2 (2014): 97-106.

Arifin, F. "Wayang Kulit Sebagai Media Pendidikan Budi Pekerti." Jantra: Jurnal Sejarah Dan Budaya 8, no. 1 (2013): 75-82.

Atkins, S.Volmink, J., S. Lewin, H. Engel, A. Fretheim, and J. Volmink. "Conducting a Meta-Ethnography of Qualitative Literature: Lessons Learnt." BMC Medical Research Methodology 8, no. 21 (2008). doi:https://doi.org/ 10.1186/1471-2288-8-21.

Duranti, A. Linguistic Anthropology. New York: Cambridge University Press, 1997.

Freire, Paulo. Education For Critical Consciousness. London: Continuum, 2005.

Geertz, C. Tafsir Kebudayaan. Yogyakarta: Penerbit Kanisius, 1992.

Hasrinuksmo, B. Ensiklopedi Wayang Indonesia. Jakarta: Sena Wangi, 1999.

Joireman, S. Nationalism and Political Identity. New York: Continuum, 2003. doi:https://doi.org/10.1057/ palgrave.cpt.9300195.

Kaplan, B., J. Liebenau, M. D. Myers, and E. Wynn. “E. Learning and Teaching Qualitative Research: A View from Reference Disciplines of History and Anthropology." In Organizational and Social Perspectives on IT, 511, 2000. http://is.lse.ac.uk/Support/ifip_wg82/Aalborg/kaplan.pdf . 
Liebenau, J., and A. Lee. "Information System and Qualitative Research." The Lancet 348, no. 9020 (1996): 127-28. doi:https://doi.org /10.1016/S0140-6736(05)64639-9.

Mulyono, S. Wayang: Asal Usul, Filsafat, Dan Masa Depannya. Jakarta: PT. Gunung Agung, 1987.

Root, B., \& Albrecht, M. "Influences of Nationalisms on Citizenship Education: Revealing a 'dark Side' in Lebanon." Nations and Nationalism, 2017.

Saussure. Course in General Linguistics. Edited by C. Bally and A. Sechehaye. New York: McGraw-Hill Book Company, n.d.

Shelton, C., and A. Smith. "On the Qualities of Qualitative Research, Qualités de La Recherche Qualitative." Canadian Journal of Anesthesia/Journal Canadien D'anesthésie 62, no. 1 (2015). doi:https://doi.org/10.1007/s12630-014-0253-3.

Trask. Key Concept in Language and Linguistic. New York: Routledge, 1999.

Wierzbicka. Semantics, Cognition, and Culture. London: Oxford University Press, 1992.

Yule. Pragmatics. Oxford: Oxford University Press, 1996. 
Vol. 14, No. 1 Juni 2017: 99-115 